Business and Economics Research Journal

Volume 8 Number 32017

pp. $533-553$

ISSN: $1309-2448$

DOI Number: 10.20409/berj.2017.65

\title{
Perceptual Image of Conflict-Ridden Destinations: An EEG and Eye Tracker Analysis $^{1}$
}

\author{
Çağatan Taşkın ${ }^{\mathrm{a}}$
}

\author{
Erdoğan Koç
}

Hakan Boz

\begin{abstract}
This study aims to investigate the perceived images of Eastern and Southeastern Anatolia regions in Turkey. These regions offer many opportunities in terms of history and culture, nature and food tourism. Using EEG and Eye Tracker devices, these two destinations, where potential tourists are blurred, and the two destinations where there are no clashes, measured levels of arousal, interest and negative value against the destination advertisements. It has been found that, with the discovery of an important element in the conflicts in the two conflicting destinations, tourists could take a small amount of risk with the intention of discovering new destinations.
\end{abstract}

Keywords: Neuromarketing, Conflict-Ridden Destinations, Destination Branding, Risk Perception, Destination Image

JEL Classification: M30, M31

\section{Introduction}

Destination branding has received considerable interest from researchers since the early 1970s (Hunt, 1971; Mayo, 1973; Gallarza et al., 2002; Pike, 2002; Martín and Rodríguez del Bosque, 2008; Dolnicar and Grün, 2013; Stepchenkova and Li, 2014).

Destination development and destination branding activities start with building a favourable destination image that identifies and differentiates the destination from its competitors (Aaker, 1991; Cai, 2002). A destination's image can be regarded as the pre-existing concept/s corresponding to that particular destination (Pike, 2009). In fact, a destination image is "the sum of beliefs, ideas, and impressions that a person has of a destination" (Crompton, 1979, p. 18).

The image of a destination brand can also be described as the "perceptions about the place as reflected by the associations held in tourists' memory" (Cai, 2002, p. 723). Many researchers view destination image as a critical part of a brand, reflected by a set of brand associations (Keller, 1993; Tasci and Kozak, 2006; Stepchenkova and Mills, 2010; Stepchenkova and Li, 2014; Taşkın and Karadamar, 2016a). This means that the image of a destination forms the basis of competitive positioning in terms of what destination offers need to be communicated both efficiently and effectively to selected target markets (Day et al., 2002; Morgan

${ }^{a}$ Assoc. Prof., PhD., Uludag University, Faculty of Economics and Administrative Sciences, Department of Business Administration, Bursa, Turkiye, ctaskin@uludag.edu.tr

bProf., PhD., Bandirma 17 Eylul University, Faculty of Economics and Administrative Sciences, Department of Business Administration, Bandırma, Turkiye, erdogankoc@yahoo.com

'Asst. Prof., PhD., Usak University, School of Applied Sciences, Department of International Trade, Usak, Turkiye, hakan.boz@usak.edu.tr 
and Pritchard, 2002; Koc, 2009; Datzira-Masip and Poluzzi, 2014; Taşkın and Karadamar, 2016b). A strong and favourable destination image reinforces a positive brand identity (Qu et al., 2011; Benedetti et al., 2011).

A destination's image is formed based on a combination of information elements such as tourists' past experience, knowledge, experiences, planned and non-planned marketing communications including word of mouth communications (Stepchenkova and Li, 2014). As holiday decisions are complex and risky, tourists engage in extended information search and generally use a variety of sources of information before making their holiday decisions (Koc, 2000 and 2009; Sirakaya and Woodside, 2005).

\section{The Main Thrust of and the Rationale for the Study}

Tourism industry can make a significant contribution to the diversification of the economy and may help alleviate regional imbalances. Besides tourism industry can provide an export opportunity which is subject to relatively high growth rates and is less constrained (e.g. greater price flexibility and better employment opportunities) than the more traditional forms of export (Fletcher, 1995). Moreover, tourism is an important industry especially for a country like Turkey due to Turkey's high multiplier value. According to Fletcher's (1995) tourism multiplier league, tourism activity in Turkey was found to have the highest multiplier value $(1,96)$ in the world to be followed by the UK, the Republic of Ireland and Egypt, with values $1.73,1.72$ and 1.23 respectively. According to a study by SKIFT (2015), an industry intelligence and marketing platform in travel and tourism, after Spain and Italy, Turkey was the third most searched country on the Internet in terms of tourism related searches, though in terms of the overall country brand strength shows that Turkey was able to be only among the top fifteen countries in the world (SKIFT, 2015). According to World Economic Forum (WEF) Travel \& Tourism Competitiveness Report (2015) the effectiveness of Turkey's marketing and branding strategy was poor with a figure of 4.8 (10 being the best). Turkey was the $58^{\text {th }}$ country in the world, out of 141 countries, in terms of the effectiveness of marketing and branding of the country as a destination.

Moreover, Turkish tourism faces major competition and it is highly vulnerable. Turkish tourism industry figures show that the tourism activity in Turkey is highly seasonal and it is mainly based on one tourism product, sun and sea tourism. Approximately $70 \%$ of tourism revenues are earned from tourists visiting Turkey between the months of April and October for sun and sea holidays.

In addition, although the number of tourists visiting Turkey has increased over the years, per person tourist spending has declined (Koc and Altinay, 2007). This is partly to do with insufficient destination development. In general Turkish destinations tend to be underdeveloped and do not have much on offer to keep tourists engaged. Average nights tourists spent/stay in Turkey is only about three days (The Turkish State Institute of Statistics, 2015), compared with, for instance the UK, with an average nights spent figure of six (EUROSTAT, 2013).

International tourism trends show that tourists are moving away from, General Interest Tourism (GIT), i.e. sun and sea type of tourism (Krippendorf, 1987a and b). Culligan (1992) suggests that the tourist's increasing desire for more novel, adventurous, and 'authentic' forms of tourism experience is a function of the decline in utility associated with a decision to simply replicate previous experience. This means that there is a move away from General Interest Tourism towards Special Interest Tourism (SIT) (Brotherton and Himmetoglu, 1997). For instance, according to World Tourism Organization whilst the nature tourism represents $8 \%$ of total tourism activity, as a segment it has grown three times faster than overall GIT (WTO, 2009). Turkey appears to have a strong potential in terms of cultural tourism due to its rich cultural resources (World Economic Forum, 2015). The country may benefit from this segment which is estimated to grow $15 \%$ per annum in the future. This figure is three times the rate of growth of general tourism (AOIFE, 2007). Moreover, as another important SIT segment food tourism has also grown $30 \%$ in the world over the past decade (Stanley and Stanley, 2014).

It may be suggested that new product and destination development are two significant challenges Turkish tourism industry needs to confront based on above explanations. This study aims to explore the present images of Eastern and South-eastern Anatolia regions as the two conflict-ridden destinations in 
Turkey, in comparison with the Mediterranean and Aegean regions as the two non-conflicted, peaceful destinations. As the conflict-ridden Eastern and South-eastern Anatolia regions are mostly undiscovered destinations by many tourists, the study particularly aims to unveil the images held in the minds of tourists with a view to provide managers with information which may be of use in making their destination development, positioning and branding decisions. These two regions collectively were classified as conflictridden places with level 4 intensity (meaning limited war) in the Heidelberg Institute for International Research report (Conflict Barometer, 2013). According to Economic Forum (WEF) Travel \& Tourism Competitiveness Report (2015), which identifies the safety and security as one of the most significant issues in tourism development, Turkey, with an average figure of 4.2 , ranks as the $121^{\text {st }}$ country in terms of safety and security. This low safety and security figure is primarily due to the terrorism incidents in and relating to the Eastern and South-eastern Anatolia regions in Turkey. However, there is a distinction in terms of the terrorism activity between these two regions, where Eastern Anatolia region is relatively much safer than the South-Eastern Anatolia region.

Turkish tourism represents about $7 \%$ of all world tourism activity in the world (WTO, 2014) according to World Tourism Organization's Tourism Highlights report (2014) with 37.8 million international tourists. This figure makes Turkey the sixth country in the world in terms of the number of international tourist arrivals (WTO, 2014). A significant proportion of Turkish landmass (about $28.5 \%$ ) lies in the Eastern and Southeastern Anatolia regions of Turkey. These two regions collectively have a landmass of approximately 228 thousand square kilometres, an area almost twice the size of the total landmass of the Netherlands, Belgium and Switzerland.

The Eastern and South-eastern Anatolia regions in Turkey are to a large extent untouched and undiscovered by both domestic and international tourists. These two regions housed many civilizations from Urartu to Mesopotamian such as Sumer and the Akkadian, Babylonian, Elam and Assyrian. The world's oldest temple in the world, Gobekli Tepe is in Sanliurfa, a city in South-eastern Turkey. This temple dates back to B.C. 11000 , i.e. about 6000 years older than Stonehenge in the U.K. There are two UNESCO World Heritage cultural sites in the region, one being Diyarbakir Fortress and Hevsel Gardens Cultural Landscape and the other one being Nemrut Dagi (UNESCO, 2015a). The city of Gaziantep in this region was listed in the Creative Cities Network by UNESCO under the category of gastronomy in 2015. It is the only Turkish city listed in the Creative Cities Network and there are only ten cities in the world listed under the gastronomy category of UNESCO Creative Cities Network (UNESCO, 2015b). The region has many natural beauties too, such as Mount Ararat ( 5137 meters high) which is believed to be the landing place of Noah's ark, according to the biblical story, and the Lake Van, the largest alkaline lake in the world (Evliyaoglu, 1994).

This huge area in the Eastern and South-eastern Anatolia regions has been almost completely excluded from any tourism activity since the establishment of PKK (Partiya Karkerên Kurdistan - The Workers Party of Kurdistan) in 1978. Since then a total of more than twelve thousand lives were lost including the security forces and the civilians. The total economic cost of the conflict was estimated to be $\$ 350$ billion between the years of 1979 and 2009. However, a roadmap for a peace process has recently started. The roadmap has already produced extremely positive consequences such as the decrease in the number of killed security staff, custodies and instigations. These positive developments in the form of a de-escalation of the conflict, are reflected in the Heidelberg Institute for International Research's report (Conflict Barometer, 2014) too, as the intensity level of conflict decreased from 4 (meaning limited war) in 2013 to 3 (meaning violent crisis) in 2014. However, some extremely severe terrorist activities, aimed at both the security forces and the civilians, started recently right after the national elections on $7^{\text {th }}$ June 2015 , both in the conflictridden regions and in various other parts of Turkey, after a reasonable period of tranquillity starting in 2009 with the establishment of National Unity and Brotherhood project (Sayari, 2016).

Based on the above, it could be stated that there are two main thrusts of this study. First, the two conflict-ridden regions in Turkey have a significant potential for both domestic and international tourism. Alongside general interest tourism, as a growing special interest tourism segment these regions could well be designed and marketed as cultural/historical, natural, and food tourism destinations (Isaac and Cakmak, 2014). Second, tourism activities may help the formation and the spreading of positive opinions about these 
regions (Cakmak and Issac, 2012) and support the acceleration of the peace process. The starting of peace process is important as Gallup's Positive Experience Index (referred to as Global Happiness Index) (GALLUP, 2015) emphasized that positive experience index scores (level of happiness) was the lowest in conflict-ridden countries. According to this survey among 148 nations in the world, Turkey with the score of 54 was the third least happy nation, being only slightly happier than countries like Tunisia and Sudan with scores of 52 and 47 respectively.

\section{Destination Image and Destination Positioning}

Three main components of destination branding identified in Jing and Rong's (2010) research are i) the development of products intimately connected with the destination; ii) efforts to develop a positive and attractive image; and iii) targeted marketing activities supported by appropriate marketing mix elements. A positive image of a destination is expected to facilitate the inflow of investments, knowledge, employees, tourists, and new businesses to the destination among competitive destinations (Clark, 2006).

Gnoth (2007) states that a destination brand encompasses cultural, social, natural, and economic values. Compared with tangible product brands, service brands, such as destinations should convey more than just the functional elements of the brand (Költringer and Dickinger, 2015), as the image of destination includes not only tangible and verifiable destination attributes, but also perceptions of more psychological nature and emotions regarding that destination (Echtner and Ritchie, 1991).

As many destinations are substitutable, due to the similarity of the features they have, a particular attention needs to be paid to the differentiation of the image of the destination in line with its' positioning (Pike, 2005). In general destination positioning studies focus on image as the key construct (Uysal et al., 2000; Chen and Uysal, 2002; Gallarza et al., 2002; Kim et al., 2005; Pike and Ryan, 2004). It is important for destination to create a distinctive image in the minds of its potential customers. Failing to do so may cause an ambiguous perception in the minds of the customers and an inability compete with the direct competitors of this destination (Gartner, 1989; Gallarza et al., 2002; Kim et al., 2005; Jeuring, 2015). It must be kept in mind that efficient and effective positioning of a destination could be a major source of competitive advantage (Kim et al. 2005; Kavaratzis and Ashworth, 2007; Pike, 2009; Turok, 2009; Braun, 2012; Zenker and Beckmann, 2013; Braun et al., 2014; Artal-Tur and Kozak, 2015).

\section{Risk Perception and Conflict-Ridden Destinations}

The main difficulties of destination branding are often associated with the complexity of tourism decisions as a destination primarily is an intangible and risky product (Cai, 2002). The possibility of risk cannot be completely avoided when purchasing a holiday, as it always involves a level of outcome uncertainty (Björk and Kauppinen-Räisänen, 2012). This is mainly to do with the fact that the tourist purchases an intangible service, an experience, and the service purchased cannot be experienced until after its purchase and use (Fakeye and Crompton, 1991; Boksberger and Craig-Smith, 2006; Björk and Kauppinen-Räisänen, 2012).

The subjective judgment of the possibility of an adverse outcome may be defined as perceived risk (Brun, 1994; Aven and Renn, 2009). The perception of the possibility of threat and danger may significantly influence tourists' holiday purchase decisions (Mansfeld, 2006; Reichel et al., 2007; Chew and Jahari, 2014). Perception of risk starts with the tourist's decision to visit a particular destination (Reisinger and Mavondo, 2005). In many instances, the quality and the quantity of information provided by various sources (Koc, 2002; Kozak and Kozak, 2008) and past experience of a destination may decrease the tourist's perception of risk. As Tversk and Kahneman's (1992) Prospect Theory puts forward people tend to put much more emphasis on the probability of negative outcomes (the probability of losing) than the probability of positive outcomes (the probability of winning).

Yet, by just participating in even many risk-free mainstream tourism activities, tourists may come across a variety of types of risks. In general, most holidays involve encounters with the unknown in terms of destinations, accommodation, and transport (Witt and Moutinho, 1995; Simpson and Siguaw, 2008; Fuchs and Reichel, 2011; Fuchs, 2013). The specific service features such as intangibility, inseparability, variability 
and perishability tend to increase the perception of risk as they may pose additional threats to tourists (Grönroos, 1990, Grönroos, 2007, Lovelock and Wirtz, 2007; Zeithaml et al; 2006; Seabra et al., 2013). Besides, tourists may also take further risks by participating in extreme sports and risky recreational activities, in which risk can be a vital component of creating memorable and satisfying experiences (Piekarz et al., 2015).

Yet, the safety of a destination remains as a central issue for tourists (Pizam et al., 1997) and determines holiday decisions significantly (Sonmez and Graefe, 1998a; Pearce, 1998; Mawby, 2000; George, 2003; Lepp and Gibson, 2003; Eitzinger and Wiedemann, 2007; George; 2010; Woosnam et al., 2015) whether to make a purchase or not. In fact, above all a destination's success is primarily dependent on the risk perceptions of tourists (Beirman, 2003).

There have been numerous studies to explore tourists' perception of risk (Verhage et al., 1990; Pizam and Mansfield, 1996; Dolnicar, 2005; Fuchs and Reichel, 2011; Björk and Kauppinen-Räisänen, 2012; Seabra et al., 2013; Bellhassen et al., 2014). Terrorism and socio-cultural risk appear to be the most significant predictors of risk perception and travel anxiety (Hall, 2002; Lean and Smyth, 2009; Hall, 2010; Fuchs and Reichel, 2011; Ozcan and Erdogan, 2015). The fragile geopolitical situation and political violence in many parts of the world increase interest in safety not by just academics but by policy makers and legislators too (Pizam and Mansfield, 1996; Prideaux and Master, 2001; Shin, 2005; Fuchs and Reichel, 2011). For instance, since March 2014, the assaults carried out by Islamic State alone has caused the killing of 650 people in cities such as Algeria, Canada, Egypt, Brussels, Istanbul, Paris and Ankara. The safety concerns are especially high for destinations that are under constant threat caused by geo-political unrest and acts of terror. It is believed that for these volatile destinations understanding tourists' risk perception may help marketers in formulating marketing strategies that will take into account the various dimensions of risk perceptions and that will mitigate some of the psychological barriers to travel (Fuchs and Reichel, 2011).According to WEF Travel and Tourism Competitiveness Report (2015) political unrest in the Middle East significantly influenced tourism activities in the region while benefitting neighbouring countries like Turkey as tourists saw these countries as alternatives to experience Middle Eastern flair and ancient sights. Though, recent attacks since 2014 by the Islamic State showed that, it is not only the Middle East that is unsafe to travel to.

A particular destination may be considered highly risky due to a recent political unrest or a terrorist attack (Sonmez and Graefe, (1998a).The political unrest, conflict, violence and terrorist attacks in a particular destination may have severe impacts on tourism (Hall, 1994; Hall and O'Sullivan, 1996; Pizam et al., 1997; Richter and Waugh, 1986; Roehl, 1995; Sonmez, 1998; Cakmak and Isaac, 2012; Belhassen et al., 2014). Research shows that tourists form images of a destination in their minds based on their perception of risk (Kozak and Kozak, 2008; Björk and Kauppinen-Räisänen, 2012).

During the 1st Gulf Crisis in 1991, after Iraq's invasion of Kuwait, tourist arrivals to Turkey from OECD (Organisation for Economic Co-operation and Development) countries declined about 36\% (Ekzen, 2004), although the instability was not directly related to Turkey. During the Gulf Crisis although the distance between the invaded city of Kuwait and Antalya, Turkey, the nearest popular destination for tourists was more than 2500 kilometres, the arrival of tourists to destination almost completely stopped due to rising risk perceptions of tourists. This means that the political instability and the ensuing threat perception can significantly influence the risk perceptions of tourists and cause a significant decline in the tourism activity both in the short and long run ((Wieviorka, 1994; Mansfeld, 2006; Hall and O'Sullivan, 1996; Lea, 1996; Pitts, 1996; Seddighi et al., 2001; Timothy et al., 2004; Neumayer, 2004; Arana and Leon, 2008; McDowell, 2008; Noy and Kohn, 2010; Simone-Charteris and Boyd, 2010; Causevic, 2011; Bellhassen et al., 2014; Chew and Jahari, 2014).

The fact that the distance between the invaded city of Kuwait and Antalya, the nearest popular destination in Turkey for visitors from OECD countries, is more than 2500 kilometres, shows the vehement influence of risk perception on tourism activities. As this particular example demonstrates political instability can not only easily reduce tourism activity in the short run, but may also influence the image of a destination in the medium to long run (Hall and O'Sullivan, 1996; Neumayer, 2004; Mansfeld, 2006; Noy and Kohn, 2010; Simone-Charteris and Boyd, 2010; Bellhassen et al., 2014; Chew and Jahari, 2014). 
According to Blain et al. (2005) the brand promise regarding a destination is important as it assures tourist in terms of the potential of pleasant and memorable holiday experience. Hence, apart from reducing the perception of various types of risks which may be associated with destination, a favourable image of a destination also provides assurance to tourist about the fact that the destination has the potential to meet the expectations of tourists(Berry, 2000; Chew and Jahari, 2014; Wong and Teoh, 2015).

\section{Methodology}

The validity and objectivity of research can be increased by the collecting data from a number of sources (Smith, 1975; Babbie, 1983; Phillips, 1985; Cheng, 2005; Bogdan and Biklen, 2006). As stated above Koc and Boz's, (2014b) found a limited use of the combined methods (triangulation in tourism research (Koc, 2015b) a shortage of the combination of methods (triangulation) used in tourism and hospitality research. In social research data collected from the participants may not reflect the truth as the participants may have certain hidden motives of which they may be unaware of. Additionally, due to impression management motives, i.e. the participants' desire to provide responses which may enable them to make a good impression on others also cause responses which may be far from the reality (Koc and Boz, 2014a; Boz, 2015).

Quite often the data collected through the accounts and evaluations of the participants may not reflect actual truth. This may be due to i) participants in research studies may have hidden motives, which even they themselves may not be aware of (Goffman, 1959; Koc and Boz, 2014a; Boz, 2015) To ensure the objectivity of the study two devices of EEG (Electroencephalogram) and Eye Tracker were used in conjunction with one another.

The purpose of this study was to measure the responses of the participants towards marketing stimuli about both conflict-ridden and non-conflict-ridden destinations by using two sensors of EEG (Electroencephalogram) and Eye Tracker. The EEG headset and Eye Tracker devices have been widely used by neuromarketers to record consumers' psychophysiological responses towards marketing stimuli, due to their ease of use (Gordon and Ciorciari, 2017)

The Eye Tracker sensor data allow decision makers to identify how much a person concentrated on various parts of a destination advertisement and where in a particular destination advertisement a potential $\mathrm{s} /$ he has looked at first (the order).

Data collected by using EEG headset device allows decision makers to determine arousal (excitement, liking and disliking), boredom /disinterest-engagement/interest, frustration, meditation/relaxation levels of tourists when looking at a particular section or a marketing cue in the advertisement. The right frontal EEG activation is associated with emotions of negative valence (disliking, disinterest, frustration and boredom) in the participants and left frontal EEG activation is associated with emotions of more positive valence (liking, interest/engagement, excitement).

\section{Marketing Stimuli used in the Study}

The marketing stimuli included package holiday advertisements for four regions (two of which conflicted and the other too being non-conflicted regions) with both visual and verbal cues (See Figure 1). Visual cues included food, nature and historical photo images relating to the particular destination for which participants' perceptions were aimed to be measured. Verbal cues included the name of the package tour (e.g. Eastern Anatolia Region) and the names of the cities to be visited in the package tour. The package holidays were similar to the brochure and the Internet advertisements for these types of holidays, except that the advertisements did not contain many details including pricing and payment so as to eliminate the influence of various factors outside the scope of this study. The EEG data both before and after the exposure to the package holiday advertisement were analyzed by using ERPs (Event Even Related Potentials (ERPs), i.e. the measured brain response that are the direct result of a specific sensory, cognitive, or motor event (Luck, 2014). 


\section{Subjects / Participants}

For the study data were obtained from 21 right handed subjects between $2^{\text {nd }}$ and $15^{\text {th }}$ May, 2015, during the period of tranquillity, before the latest serious terrorist attacks in Turkey following the national elections on $7^{\text {th }}$ June 2015. The use of right handed participants is due to the fact that these individuals are more likely to perform a specific task in either the right or left hemisphere in the brain. On the other hand, left handed people are more likely to perform a specific task equally both in their right and the left hemisphere's (Martin and Jones, 2009). The participants were chosen from people who never went to the conflict-ridden regions nor had any close relationship with these regions. In order to avoid bias participants were chosen from voluntary potential tourists selected from the customer databank of a travel agency. The participants were not paid for taking part in the study.

The ages of the participants ranged from 20 to 53 years old. All subjects voluntarily participated in the experiment. Subjects had no previous history of any psychiatric, psychological and neurological disorders, and no alcohol or drug dependence. Of the 21 participants 15 of them were males and 6 of them were females. The sample size may be thought to be limited for traditional questionnaire surveys. However, there are many neuromarketing studies similar sample sizes such as Hedgcock et al., 2012; Valenzi et al., 2014; Dimpfel, 2015; Falk et al., 2010 and Menéndez, 2015). Before the start of the experiment, each participant was informed briefly about the study procedure and the EEG and Eye Tracker devices.

\section{The Task and Experimental Procedure}

In order to explore the images potential tourists may have for the conflict-ridden destinations in Turkey (Eastern and South-eastern Anatolia regions) promotional materials (destination advertisements) with visual and written verbal cues were prepared and pilot tested. Promotional materials (destination advertisements) with visual and verbal cues were designed for two conflict-ridden and two non-conflictridden (peaceful) regions in Turkey, Eastern Anatolia, South-eastern Anatolia, Aegean and Mediterranean regions respectively.

Each region was thought as a destination and advertisements were organised around separate package tours for each destination region. As mentioned above the package tour holiday comprised verbal messages including the names of the cities in the region with visual images focusing on themes of based on the themes of historical sightseeing, local food and natural beauties in these regions, due to the growth rate of these segments, as explained above in the literature.

Figure 1. Flowchart of the Experiment

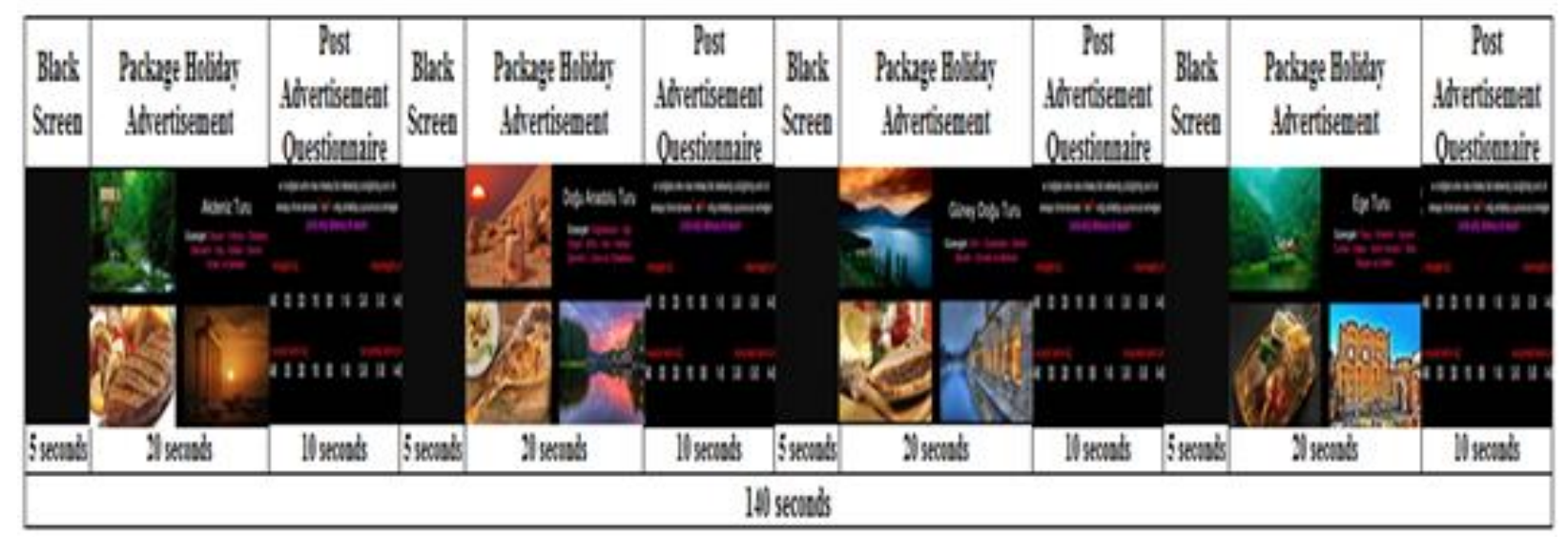

The participants in the experiment were shown four package holiday stimuli, i.e. destination advertisements (as shown in Figure 1) (both from the conflicted regions of Eastern and South-Eastern Anatolia and non-conflicted regions of the Aegean and Mediterranean in Turkey) and their emotions were detected simultaneously using the Affectiv Suite ${ }^{\mathrm{TM}}$ software (for monitoring the user's emotional states) 
provided by Emotiv System Co. The experimental paradigm and the details of the experimental procedure are shown in Figure 1 and Table 1 respectively.

Table 1. Experimental Procedure

\begin{tabular}{|c|c|}
\hline 1 & $\begin{array}{l}\text { In order to avoid the order effect the visual destination marketing materials were shown } \\
\text { randomly to the participants. }\end{array}$ \\
\hline 2 & The duration of the experiment was 140 seconds for each participant. \\
\hline 3 & $\begin{array}{l}\text { After the placement of EEG, HR and GSR apparatuses subjects were asked to take a comfortable } \\
\text { position and relax. Participants ran the experiment individually using a mouse to answer } \\
\text { assessment questionnaires. }\end{array}$ \\
\hline 4 & $\begin{array}{l}\text { First visual destination marketing material was shown five seconds after the experiment started. } \\
\text { During these five seconds the participants were shown a black screen. }\end{array}$ \\
\hline 5 & $\begin{array}{l}\text { After having being exposed to marketing stimuli participants were asked to make an evaluation } \\
\text { for duration of ten seconds and indicate their responses on the screen by using the mouse. }\end{array}$ \\
\hline 6 & $\begin{array}{l}\text { The participants indicated their responses on a Likert scale A - } 4 \text { (minus four) score meant "I } \\
\text { definitely did not like this holiday advertisement?" or "I would definitely not purchase this } \\
\text { holiday" and a score of }+4 \text { meant "I definitely liked this holiday" or "I would definitely buy this } \\
\text { holiday" on the screen with the mouse. }\end{array}$ \\
\hline 7 & The experiment was carried out in a quiet room. \\
\hline 8 & $\begin{array}{l}\text { To relax the participants the process of showing visual destination marketing materials started } \\
4-5 \text { minutes after the placement of the EEG, HR and GSR sensors and the calibration of the Eye } \\
\text { Tracker sensor. }\end{array}$ \\
\hline 9 & $\begin{array}{l}\text { To relax the participants the process of showing visual destination marketing materials started } \\
4-5 \text { minutes after the placement of the EEG, HR and GSR sensors and the calibration of the Eye } \\
\text { Tracker sensor. }\end{array}$ \\
\hline 10 & Subjects were instructed to avoid any excess movements during the experiment. \\
\hline 11 & Each visual destination marketing material was shown for a duration of 20 seconds. \\
\hline 12 & $\begin{array}{l}\text { Between each of the four destination marketing advertisements the participants were shown a } \\
\text { black screen for five seconds. }\end{array}$ \\
\hline
\end{tabular}

As explained and shown in Figure 1 and Table 1 above during the experimental procedure the participants were shown initially black screen as a baseline procedure to determine each participant's "resting state" for five seconds by using EEG. The emotion elicitation started following the baseline procedure. During this stage the participants were shown the package holiday advertisements randomly so as to eliminate the order effect. The emotion elicitation process lasted 20 seconds. After viewing a package holiday advertisement for 20 seconds, each participant was given 10 seconds to respond to a self-report questionnaire shown on the screen to indicate her/his emotional state by using a computer mouse. In particular, the participant was asked to indicate the degree of pleasantness of the advertisement and her/his purchase intention for that particular package holiday advertised on 9 point scale. After the completion of each questionnaire following each package holiday advertisement, the participant was shown the next package holiday advertisement.

\section{Findings and Analysis}

The first analysis of the study was based on the survey responses of the participants' on the degree of pleasantness (two questions) and their purchase intentions (2 questions) for each package holiday advertisement they viewed for 20 seconds. The participants indicated their responses by using their mouse on the options shown on the computer screen by using the mouse. The responses ranged from "I did not like it at all" (for pleasantness) and "I definitely do not wish to purchase" (purchase intention) (-4) to "I liked it very much" (for pleasantness) and "I definitely wish to purchase" (purchase intention) (4). 
Table 2 shows a comparison of liking and purchase intentions of the participants for conflicted and nonconflicted, i.e. peaceful, regions based on their own evaluations. The second row of the table shows their purchasing intentions of the participants who liked the particular package holiday, and the third row shows a ratio of this.

Table 2. Liking and Purchase Intention Rates

\begin{tabular}{|l|c|c|c|c|c|c|}
\cline { 2 - 7 } \multicolumn{1}{c|}{} & $\begin{array}{c}\text { Eastern } \\
\text { Anatolia }\end{array}$ & $\begin{array}{c}\text { South - } \\
\text { eastern } \\
\text { Anatolia }\end{array}$ & Aegean & Mediterranean & \multicolumn{2}{c|}{ Total Average } \\
\cline { 2 - 7 } & 1,17 & 1,07 & 2,37 & 2,43 & 1,12 & 2,40 \\
\hline Pleasantness Mean & 0,60 & 0,57 & 2,13 & 2,33 & 0,58 & 2,23 \\
\hline Purchase Intention Mean & Regions & $\begin{array}{c}\text { Non- } \\
\text { conflicted } \\
\text { Regions }\end{array}$ \\
\hline $\begin{array}{l}\text { Purchase } \\
\text { Intention/Pleasantness }\end{array}$ & $51,43 \%$ & $53,44 \%$ & $90,14 \%$ & $95,89 \%$ & $52,43 \%$ & $93,02 \%$ \\
\hline
\end{tabular}

It can be seen in Table 2 that both liking and purchase intentions of the participants for non-conflictridden / peaceful destinations (Aegean the Mediterranean region) are significantly higher (almost 100\%) than for conflict-ridden destinations (Eastern and South-eastern Anatolia Regions). This may be attributable to the risk perceptions of tourists regarding the conflict-ridden destinations even after a reasonable period of tranquillity. This finding is in line with many previous research studies mentioned above (Pizam et al., 1997; Sonmez and Graefe, 1998; Pearce, 1998; Mawby, 2000; George, 2003; Beirman, 2003; Lepp and Gibson, 2003; Eitzinger and Wiedemann, 2007; George; 2010; Woosnam et al., 2015). In other words, it can be stated that physical risk may decrease liking and purchase intentions of a destination (Hall, 1994; Hall and O'Sullivan, 1996; Pizam et al., 1997; Richter and Waugh, 1986; Roehl, 1995; Sonmez, 1998c; Neumayer, 2004; Cakmak and Isaac, 2012; Bellhassen et al., 2014). A high level of risk perception even after a reasonable period of tranquillity, between 2009 and 2015, may be attributed to cultural characteristics. According to Hofstede's cross-cultural dimensions, in general Turkish culture may be classified as a highly risk averse culture (with a score of 85) and low indulgence culture, i.e. a restrained culture (with a score of 49) (Hofstede et al, 2015). In restrained cultures (as opposed to indulgence) in general people are more likely to remember negative emotions (Hofstede et al, 2015).

A paired-samples t-test was conducted to compare the periods prior to the showing of each destination advertisement and the actual period the destination advertisement is shown in terms of arousal, interest and negative valence scores. According to the test results there were no significant differences in the scores for arousal prior to the period of the Eastern Anatolia region package holiday advertisement is shown $(M=40,11, S D=11,88)$ and the Eastern Anatolia region package holiday advertisement is shown $(M=42,60$, $\mathrm{SD}=11,83) ; \mathrm{t}(20)=-, 630, \mathrm{p}=, 54$, the period prior to the Aegean region package holiday advertisement is shown $(M=50,30, S D=17,45)$ and the period the Aegean region package holiday advertisement is shown $(M=47,64, S D=11,05) ; t(20)=, 782, p=, 443$, the period prior to the South-Eastern Anatolia region package holiday advertisement is shown $(M=43,68, S D=12,69)$ and the period the South-eastern Anatolia region package holiday advertisement is shown $(M=42,89, S D=14,65) ; t(20)=, 264, p=, 794$ and the period of the Mediterranean region advertisement is shown $(M=55,12, S D=17,76)$ and the period the Mediterranean region advertisement is shown $(M=49,73, S D=15,87) ; t(20)=1,750, p=, 095$.

The above figures of arousal shows that the average level of arousal for the advertisements of conflicted regions (the Eastern Anatolia: 42,60 and the South-eastern Anatolia:42.89) is much lower than the average level of arousal for the non-conflicted regions (the Aegean: 47,64 and the Mediterranean: 49,73). 
This finding is in line with the findings of a number of studies which found that changes in experienced joyfulness resulted in higher levels of arousal (Jong-Meyer, 1990 and 1991; Simons et al., 1999; Reeves, Lang, Kim, \& Tatar, 1999; Lang et al., 1999 and 2000; Bolls et al., 2001).

According to the test results there were no significant differences in the scores of interest prior to the period of the Eastern Anatolia region package holiday advertisement $(M=76,57, S D=11,29)$ and the period Eastern Anatolia advertisement package holiday advertisement is shown $(M=76,14, S D=12,69) ; t(20)=$ $198, p=, 845$, the period prior to the showing of Aegean region package holiday advertisement is shown $(M=75,00, S D=11,15)$ and the period the Aegean region package holiday advertisement is shown $(M=71,57$, $S D=11,05) ; t(20)=2,073, p=, 051$, the period prior the South-eastern Anatolia region package holiday advertisement is shown $(M=70,23, S D=12,17)$ and the period the South-eastern Anatolia package holiday advertisement is shown $(M=66,95, S D=11,59) ; t(20)=1,842, p=, 080$, the period prior to the Mediterranean region package holiday advertisement is shown $(M=68,57, S D=8,46)$ and the period the Mediterranean region package holiday advertisement is shown $(M=67,52, S D=7,69) ; t(20)=, 732, p=, 473$.

An analysis of the above figures show that the highest average level of interest was for the Eastern Anatolia Region $(76,14)$ and the lowest level of interest was for the South Eastern Anatolia Region $(66,95)$. As explained in the literature, though some terrorism activity occurs from time to time in the Eastern Anatolia Region, it is much safer than the South Eastern Anatolia region. The interest levels for two non-conflicted regions (i.e. the Aegean and the Mediterranean) are lower (71, 75 and 67,72 respectively) than the Eastern Anatolia region. As explained in the literature this may be attributable to the decline in utility associated with a decision to simply replicate previous experience as these regions may have been visited by tourist for sun and sea tourism activities frequently (Krippendorf, 1987a and b; Culligan, 1992; Brotherton and Himmetoglu, 1997; Koc, 2005). The highest average level of interest for the Eastern Anatolia Region may mean that tourist may overlook small amount of risk at the expense of exploring new destinations.

According to the test results there were no significant differences in the scores for negative valence (frustration) prior to the period of the Eastern Anatolia region package holiday advertisement is shown $(\mathrm{M}=65,34, \mathrm{SD}=17,97)$ and the period the Eastern Anatolia region package holiday advertisement is shown $(M=57,86, S D=15,21) ; t(20)=1,443, p=, 165$ and period prior to the Aegean region package holiday advertisement is shown $(M=65,99, S D=12,99)$ and the period the Aegean region package holiday advertisement is shown $(M=62,43, S D=12,61) ; t(20)=, 943, p=, 357$. There were significant differences between the period prior to the South-eastern Anatolia region package holiday advertisement is shown ( $\mathrm{M}=$ $60,44, S D=12,06)$ and the period South-eastern Anatolia Region package holiday advertisement is shown $(\mathrm{M}=53,09, \mathrm{SD}=10,81) ; \mathrm{t}(20)=2,18, \mathrm{p}=, 041$, the period prior to the Mediterranean region package holiday advertisement is shown $(M=63,34, S D=17,75)$ and the period the Mediterranean region package holiday advertisement is shown $(M=52,60, S D=12,32) ; t(20)=2,542, p=, 019$.

Table 3. Paired-samples T Test Results

\begin{tabular}{|c|c|c|c|c|c|c|c|c|c|c|}
\hline & $\begin{array}{c}\text { The period prior } \\
\text { to the showing } \\
\text { of Eastern } \\
\text { Anatolia region } \\
\text { advertisement }\end{array}$ & $\begin{array}{c}\text { The actual } \\
\text { period the } \\
\text { Eastern } \\
\text { Anatolia region } \\
\text { advertisement } \\
\text { is shown }\end{array}$ & t-test & \multicolumn{2}{|c|}{$\begin{array}{c}\text { The period } \\
\text { prior to the } \\
\text { showing of } \\
\text { Aegean } \\
\text { Anatolia region } \\
\text { advertisement }\end{array}$} & $\begin{array}{c}\text { The actual } \\
\text { period the } \\
\text { Aegean } \\
\text { Anatolia region } \\
\text { advertisement } \\
\text { is shown }\end{array}$ & t-test \\
\hline & $\mathrm{M}$ & $\mathrm{SD}$ & $\mathrm{M}$ & $\mathrm{SD}$ & & $\mathrm{M}$ & $\mathrm{SD}$ & $\mathrm{M}$ & $\mathrm{SD}$ & \\
\hline Arousal & 40,11 & 11,88 & 42,60 & 11,83 & $-0,63$ & 50,30 & 17,45 & 47,64 & 11,05 & 0,782 \\
\hline Interest & 76,57 & 11,29 & 76,14 & 12,69 & 0,198 & 75,00 & 11,15 & 71,57 & 11,05 & 2,073 \\
\hline $\begin{array}{c}\text { Negative } \\
\text { Valence }\end{array}$ & 65,34 & 17,97 & 57,86 & 15,21 & 1,443 & 65,99 & 12,99 & 62,43 & 12,61 & 0,943 \\
\hline
\end{tabular}


Table 4. Paired-samples T Test Results

\begin{tabular}{|c|c|c|c|c|c|c|c|c|c|c|}
\hline & \multicolumn{2}{|c|}{$\begin{array}{l}\text { The period } \\
\text { prior to the } \\
\text { showing of } \\
\text { South-Eastern } \\
\text { Anatolia region } \\
\text { advertisement }\end{array}$} & \multicolumn{2}{|c|}{$\begin{array}{c}\text { The actual } \\
\text { period the } \\
\text { South-Eastern } \\
\text { Anatolia region } \\
\text { advertisement } \\
\text { is shown }\end{array}$} & \multirow[t]{2}{*}{ t-test } & \multicolumn{2}{|c|}{$\begin{array}{c}\text { The period prior } \\
\text { to the showing } \\
\text { of } \\
\text { Mediterranean } \\
\text { Anatolia region } \\
\text { advertisement }\end{array}$} & \multicolumn{2}{|c|}{$\begin{array}{l}\text { The actual } \\
\text { period the } \\
\text { Mediterranean } \\
\text { Anatolia region } \\
\text { advertisement } \\
\text { is shown }\end{array}$} & \multirow[t]{2}{*}{ t-test } \\
\hline & $M$ & SD & $M$ & SD & & $M$ & SD & $M$ & SD & \\
\hline Arousal & 43,68 & 12,69 & 42,89 & 14,65 & 0,264 & 55,12 & 17,76 & 49,73 & 15,87 & 1,75 \\
\hline Interest & 70,23 & 12,17 & 66,95 & 11,59 & 1,842 & 68,57 & 8,46 & 67,52 & 7,69 & 0,732 \\
\hline $\begin{array}{l}\text { Negative } \\
\text { Valence }\end{array}$ & 60,44 & 12,06 & 53,09 & 10,81 & $\begin{array}{l}2,18^{*} \\
p<0,05\end{array}$ & 63,34 & 17,75 & 52,60 & 12,32 & $\begin{array}{r}2,542^{*} \\
p<0,05\end{array}$ \\
\hline
\end{tabular}

Figures 2 and 3 shows the heat / attention map data collected by the Eye Tracker and together with data collected by EEG device for the destinations Eastern Anatolia, the Aegean, the South-eastern Anatolia and the Mediterranean regions respectively. As stated in the methodology section the participants were shown a black screen for five seconds before each advertising stimuli i.e., destination advertisements (vertical lines separating the showing of each stimuli - 0-5, 25-30, 50-55 and 75-80 seconds) to eliminate cross influences.

Figure 2. Number of Eye Fixations

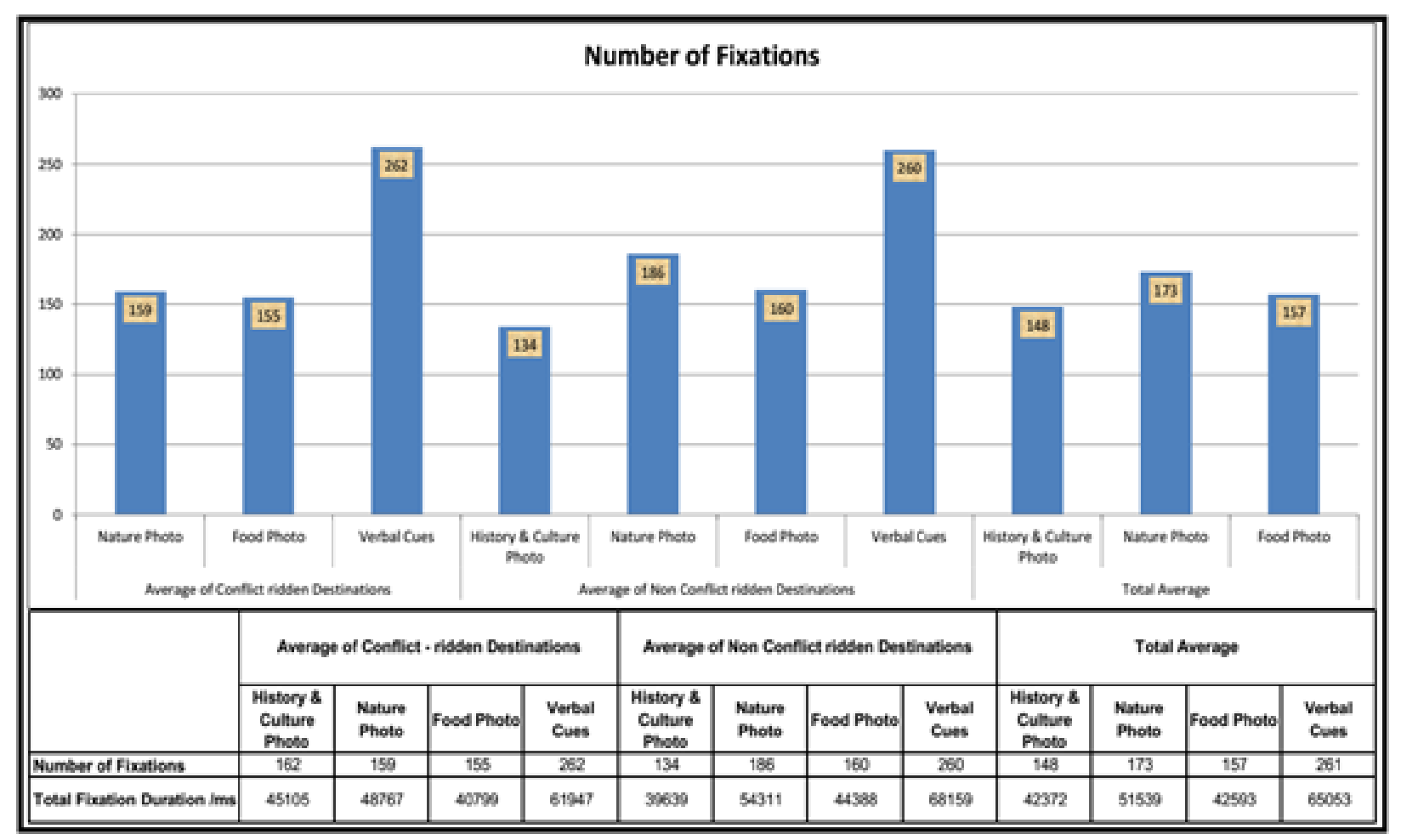

Figures 2 and 3 show that participants had the highest level of arousals when they were looking at advertisements of non-conflict-ridden destinations, i.e. the Aegean and Mediterranean regions. When average arousal figures were presented above it was seen that the average level of arousal for conflicted regions (the Eastern Anatolia: 42,60 and the South-eastern Anatolia:42.89) is much lower than the average level of arousal for the non-conflicted regions (the Aegean: 47,64 and the Mediterranean: 49,73). It was stated above that this finding was in line with a number of studies such as Jong-Meyer, 1990 and 1991 ; Simons et al., 1999; Reeves, Lang, Kim, \& Tatar, 1999; Lang et al., 1999 and 2000; Bolls et al., 2001). 
The Pearson correlation analysis shows that there was a significant correlation between the level of pleasantness and purchase intention and moderate level of correlation with interest $\left(r=-, 56, p<0,01, r^{2}=0,31\right)$ and arousal $\left(r=67, p<0,01, r^{2}=0,45\right)$. A positive high level of correlation is normally expected between pleasantness and arousal (Vecchiato et al., 2015).

Additionally, the level of interest is negatively significant correlated with level of arousal $(r=-, 21$, $\left.p<0,05, r^{2}=0,04\right)$. There was small correlation between arousal and the level of interest and negative valence. The level of interest, the level of negative valence $\left(r=47, p<0,01, r^{2}=0,22\right)$ were positively significantly correlated.

Research shows that there is positive relationship between the level of arousal of consumers and their intention to make a purchase (Baker et al., 1992; Sheng and Joginapelly, 2012). Moreover, the feeling of pleasure also influences intention to make a purchase (Baker et al., 1992; Sheng and Joginapelly, 2012). When consumers are exposed to a pleasant marketing stimuli, their level of interest and engagement appear to increase (Lang, 1995). However, negative stimuli alos increase the level of arousal of consumers but leads to negative feelings such as frustration or anxiety (Lang, 1995; Sheng and Joginapelly, 2012).

A heat map was produced based on the data collected. The heat map shows the emotional responses of the participants towards the visual marketing stimuli they were exposed to.

Figure 3. Heat map of the Participants towards Destination Advertisements

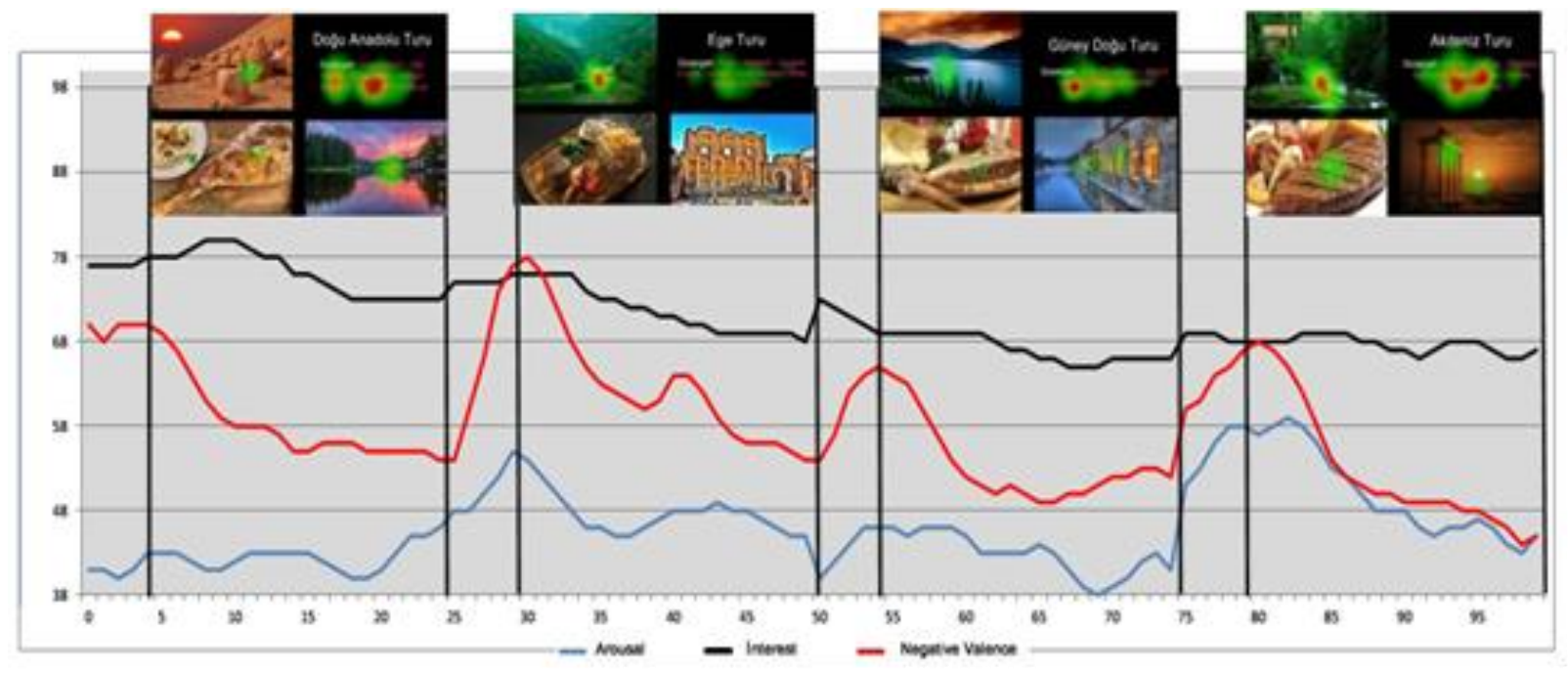

The data collected through the Eye Tracker device (Figures 2 and 3) shows that in general total fixation periods for verbal cues were relatively significantly higher than all other features of the advertisements. The findings bear similarities with Rayner et al.'s (2001 and 2008) and Lykins et al's. (2006) neuromarketing studies which investigated the evaluations of participants in terms of whether they found a particular advertisement pleasant and whether they would buy that particular product or service advertised (i.e. their purchase intentions). In Rayner et al.'s (2001 and 2008) findings demonstrated that when customers were asked to make a purchase they tended to look at text stimuli more often than the pictorial stimuli provided in the advertisement. However, when customers were asked to evaluate the pleasantness or effectiveness of the advertisements, they tended to fixate more on the pictorial stimuli than the text stimuli in the advertisements (Seo et al., 2010). Hence, the increased number of fixations may be due to the amount of attention a customer pays to a stimuli (Lykins et al., 2006; Rayner et al., 2008; Deans et al., 2010; Seo et al., 2010). Hence, the increased number of eye fixations in this study may be due to the need to read (Seo et al., 2010; Ho and Chua, 2013). Total amount of the eye resting on visual stimuli shows the fact that the customer is interested in the specific stimuli (Lykins et al., 2006; Seo et al., 2010). 
Fixation periods at the verbal cues in the advertisements may be to do with the loss aversion motivation (Kahneman and Tversky, 1992) of participants as details to pay attention are usually in written details in the advertisements. Emotions can perhaps be better expressed through photos, while facts relating to terms and conditions can be better expressed though verbal cues (Koc, 2000). This is reasonable, although holidays are hedonic experiences, they can be high risk purchases as explained above (Fakeye and Crompton, 1991; Sirakaya and Woodside, 2005; Boksberger and Craig-Smith, 2006; Björk and Kauppinen-Räisänen, 2012; Fyall et al., 2012; Wong and Teoh, 2015).

This is due to the fact that tourism decisions involve high level of various types of risks (e.g. physiological, financial, social, psychological and time) (Hall, 1994; Hall and O'Sullivan, 1996; Pizam et al., 1997; Richter and Waugh, 1986; Roehl, 1995; Sonmez, 1998a; Neumayer, 2004; Cakmak and Isaac, 2012; Bellhassen et al., 2014). However, it is interesting to see that in general the fixation periods on verbal cues were relatively high. The total fixation duration for the conflict-ridden destinations is relatively lower compared with the total fixation duration for the non-conflict-ridden destinations. This may be due to the risk associated with the conflict-ridden destinations. The participants may not really think of going to these destinations as a holiday option and hence concentrate more on the verbal cues of non-conflict ridden destinations.

The fixation count data show variations among the destinations. The number of fixations on history and culture photos of conflict-ridden destinations (162) is higher than the number of fixations on history and culture photos of non-conflict-ridden destinations (134). The total fixation duration for conflict-ridden destinations is also higher $(45105 \mathrm{~ms})$ than the total fixation duration for non-conflict-ridden destinations (39639 ms). This may attributable to the fact that the historical and cultural features of the conflicted destinations are mostly unknown for most tourists. Tourists may be curious to explore the undiscovered historical and cultural aspects of the conflicted destinations (Eastern and South-eastern Anatolia regions). Tourists may be more familiar with the historical and cultural features of the non-conflict-ridden destinations.

For both non-conflict-ridden and non-conflict-ridden destinations both the number of fixations and the duration of fixations were relatively lower for food photos. This may be attributable to two factors. First, as a concept the culinary or food tourism has not yet developed sufficiently in Turkey. Second, as there is a widespread tradition of all-inclusive holidays, and in general tourists in Turkey tend to have an extensive experience of these types of holidays and they may not believe that they will really find local and ethnic cuisine in these holidays. Due to widespread experience of all-inclusive type of lodging tourists may expect to find standard food they may get anywhere else in Turkey. As discussed in the literature review (Krippendorf, 1987a and b; Zauhar, 1994) there is a need for the development of various types of special interest tourism products and special interest tourism destinations in Turkey. Based on this finding it may be suggested that in both conflict-ridden and non-conflict-ridden regions the hospitality establishments may concentrate on their menus and try to offer ethnic and exotic meals. It may be especially the case for the conflict-ridden regions as these regions offer extensive opportunities from a food tourism perspective. Hence, the conflict-ridden destinations may be suggested to position themselves around food and culinary tourism and avoid all-inclusive type of lodgement. The findings of this study are parallel with the findings of a number of neuromarketing studies (e.g. Goldberg et al., 1999; Bialkova and van Trijp, 2010; Bialkova and van Trijp, 2011; Graham and Jeffery, 2012; Van Loo et al., 2015; Samant and Seo, 2016) which found that participants spent longer time in looking at items that they considered purchasing.

\section{Conclusions}

The results of the study show the significant influence of risk and danger on the perceptual image of a destination. It is also seen that although the risk associated with a conflict-ridden destination may be fairly permanent, tourists may overlook a lower level of risk at the expense of discovering new destinations. Tourist's average level of interest for the Eastern Anatolia, a relatively safer region of the two conflicted regions, was the highest. 
One strategy for the destination planners and practitioners may be to allow a longer period of time to fade away the risk and danger associated with a conflict-ridden destination. Destination planners and practitioners may then start developing destination image and related positioning strategies.

An additional strategy may be to start destination development activities as soon as possible in these two conflicted regions. The association of risk and danger with a conflict-ridden destination, even after a reasonable period of peace and calmness, may be to do with priming in the minds of potential tourists. This means that with a Pavlovian conditioning, whenever a conflict-ridden destination is mentioned, individuals may tend to produce pre-recorded risk and danger related responses. The practitioners may be recommended to carry out marketing communications activities to eliminate the priming in the minds of potential tourists. Additionally, policy makers may concentrate on organizing festivals and various events to reduce the perception of risks associated with these regions.

As holidays are risky purchases and risky aspects of holidays tend to be communicated through verbal cues rather than visual cues (photos), tourists tend to concentrate more on verbal cues. For this reason, destination planners and managers in holiday establishments, both in conflict-ridden and non-conflict ridden destinations, are advised to pay a particular attention to the planning and designing of verbal cues. Additionally, in line with recent trends in tourism activity in terms of a move from GIT to SIT, tourists tend to pay more attention to cultural and historical aspects of a destination, rather than the features of a holiday establishment. Hence practitioners may be recommended to concentrate more on the historical and cultural aspects of a destination.

The findings of the study show that although tourists may be curious to explore the conflict-ridden destinations of Eastern and South-eastern Anatolia they are still wary of the risks. Had the study been implemented after the severe attacks following the national elections in Turkey on $7^{\text {th }}$ June 2015, the level of risk tourists felt would have been significantly higher. It may also be recommended that the two conflictridden destinations of Eastern and South-eastern Anatolia may be best positioned around the theme of cultural and natural tourism. Although this region is famous for its rich variety of ethnic and exotic foods, as Turkish tourists have extensive experience of open buffet all-inclusive package holidays, tourists do not tend to be convinced by ethnic and exotic food claims. This may also be to do with the fact that food and culinary tourism has not yet developed in Turkey. The practitioners may be recommended to work on developing food and culinary tourism market in Turkey, not only for domestic tourists, but also for international tourists too.

\section{End Notes}

1. This research was presented in International Congress of Management, Economy and Policy (ICOMEP), 26-27 November, istanbul.

\section{References}

AOIFE (Association of Irish Festival Events). (2007). Cultural tourism: Making it work for you-A new strategy for cultural tourism in Ireland. Fáilte Ireland, Dublin. Retrieved October 01, 2015 from:http://www.aoifeonline.com/uplds/cultural-tourism.pdf

Aaker, D. (1991). Managing brand equity: Capitalizing on the value of a brand name. New York: Free Press.

Araña, J. E., \& León, C. J. (2008). The impact of terrorism on tourism demand. Annals of Tourism Research, 35(2), 31299.

Artal-Tur, A., \& Kozak, M. (Eds.). (2015). Destination Competitiveness, the Environment and Sustainability: Challenges and Cases. CABI Series in Tourism Management Research (Vol. 2). CAB

Aven, T., \& Renn, O. (2009). On risk defined as an event where the outcome is uncertain. Journal of Risk Research, 12(1), $1-11$

Babbie, E. R. (1983). The practice of social research (3rd ed.). Belmont. CA: Wadsworth 
Baker, J., Levy, M., \& Grewal, D. (1992). An experimental approach to making retail store environmental decisions. Journal of Retailing (68) 4, 445-460.

Beirman, D. (2003). Restoring tourism destinations in crisis: A strategic marketing approach. Sydney: Allen \& Unwin.

Belhassen, Y., Uriely, N., \& Assor, O. (2014). The touristification of a conflict zone: The case of Bil'in. Annals of Tourism Research, 49, 174-189.

Benedetti, J., Çakmak, E., \& Dinnie, K. (2011).The competitive identity of Brazil as a Dutch holiday destination. Place Branding and Public Diplomacy, 7(2), 107-115.

Berry, L. (2000). Cultivating service brand equity. Journal of the Academy of Marketing Science, 28(1), 128-137.

Bialkova, S.,\& van Trijp, H. (2010). What determines consumer attention to nutrition labels?. Food Quality and Preference, 21, 1042-1051.

Bialkova, S.,\& van Trijp, H. C. (2011). An efficient methodology for assessing attention to and effect of nutrition information displayed front-of-pack. Food Quality and Preference, 22(6), 592-601.

Björk, P., \& Kauppinen-Räisänen, H. (2012). A netnographic examination of travelers' online discussions of risks. Tourism Management Perspectives, 2, 65-71.

Blain, C.,Levy,S.E.,\&Ritchie,B.(2005).Destination branding: Insights and practices from destination management organizations. Journal of Travel Research, 43(4), 328-338.

Bogdan, R. C. and Biklen, S. K. (2006).Qualitative research in education: An introduction to theory and methods (5th ed.). Boston: Allyn and Bacon.

Boksberger, P. E., \& Craig-Smith, S. J. (2006). Customer value amongst tourists: A conceptual framework and a riskadjusted model. Tourism Review, 61(1), 6-12.

Bolls, P. D., Lang, A., \& Potter, R. F. (2001). The effects of message valence and listener arousal on attention, memory, and facial muscular responses to radio advertisements. Communication Research, 28(5), 627-651.

Boz, H. (2015). Turistik ürün satn alma karar sürecinde itkiselliğin rolü: Psikonörobiyokimyasal analiz. Unpublished Doctoral Thesis, Balikesir University, Institute of Social Sciences, Balikesir, Turkey.

Braun, E. (2012). Putting city branding into practice. Journal of Brand Management, 19(4), 257-267.

Braun, E., Eshuis, J., \& Klijn, E. H. (2014).The effectiveness of place brand communication. Cities, 41, 64-70.

Brun, W. (1994). Risk perception: Main issues, approaches and findings. In G.Wright, \& P. Ayton (Eds.), Subjective probability (pp. 295-320). Chichester: John Wiley \& Sons.

Brotherton, B., \& Himmetoglu, B. (1997). Beyond destinations-special interest tourism. Anatolia: An International Journal of Tourism and Hospitality Research, 8(3), 11-30.

Bruwer, J., Pratt, M. A., Saliba, A., \& Hirche, M. (2014). Regional destination image perception of tourists within a winescape context. Current Issues in Tourism, (ahead-of-print), 1-21.

Cai, A. (2002). Cooperative branding for rural destinations. Annals of Tourism Research, 29(3), 720-742.

Cakmak , E. \& Isaac, R.K. (2012). What destination marketers can learn from their visitors' blogs: An image analysis of Bethlehem, Palestine. Journal of Destination Marketing and Management, 1(1-2), 124-133.

Chen, J. S., \& Uysal M. 2002. Marketing positioning analysis: A hybrid approach. Annals of Tourism Research, 29(4): 9871003.

Cheng, L. (2005). Changing language teaching through language testing: A washback study. Studies in language testing, 21. Cambridge: Cambridge University Press.

Chew, E. Y. T., \& Jahari, S. A. (2014). Destination image as a mediator between perceived risks and revisit intention: A case of post-disaster Japan. Tourism Management, 40, 382-393.

Clark, G. (2006). City marketing and economic development. In Paper presented at the International City Marketing Summit, Madrid, Spain. Retrieved October 15, 2015, from 〈http://www.madrid.es/UnidadWeb/Contenidos/Especiallnformativo/Rela cInternac/MadridGlobal/Ficheros/InformesGenerales/Greg_Clark.pdf).

Conflict Barometer (2013), Heidelberg Institute for International Research report, Retrieved March 20, 2015 from http://www.hiik.de/en/konfliktbarometer/pdf/ConflictBarometer_2013.pdf.

Conflict Barometer (2014), Heidelberg Institute for International Research report, Retrieved March 20, 2015 from http://www.hiik.de/en/konfliktbarometer/pdf/ConflictBarometer_2014.pdf. 
Crompton, J. L. (1979). An assessment of the image of Mexico as a vacation destination and the influence of geographical location upon that image. Journal of Travel Research, 17(1), 18-23.

Culligan, K. (1992). Developing a model of holiday taking behaviour. Leisure and tourism futures conference proceedings, London: The Henley Centre for Forecasting.

Datzira-Masip, J., \& Poluzzi, A. (2014). Brand architecture management: The case of four tourist destinations in Catalonia. Journal of Destination Marketing \& Management, 3(1), 48-58.

Day, J., Skidmore, S., \& Koller, T. (2002). Image selection in destination positioning: A new approach. Journal of Vacation Marketing, 8(2), 177-186.

Deans, P., O'Laughlin, L., Brubaker, B., Gay, N., \& Krug, D. (2010). Use of eye movement tracking in the differential diagnosis of attention deficit hyperactivity disorder (ADHD) andreading disability. Psychology, 1(4), 238-246.

Dimpfel, W. (2015). Neuromarketing: Neurocode-tracking in combination with eye-tracking for quantitative objective assessment of TV commercias. Journal of Behavioral and Brain Science, 5(04), 137.

Dolnicar, S. (2005). Understanding barriers to leisure travel: tourist fears as a marketing basis. Journal of Vacation Marketing, 11(3), 197-208.

Dolnicar, S., \& Grün, B. (2013). Validly measuring destination image in survey studies. Journal of Travel Research, 52(1), 3-14.

Echtner, C. M., \& Ritchie, J. R. B. (1991). The meaning and measurement of destination image. The Journal of Tourism Studies, 2(2), 2-12.

Eitzinger, C., \& Wiedemann, P. (2007). Risk perceptions in the alpine tourist destination Tyrol-An exploratory analysis of residents' views. Tourism Management, 28(3), 911-916..

Ekzen, N. (2004). 1991 Körfez Krizinin Türk Turizmine Etkileri, Turizm Gazetesi, Retrieved September 14, 2015, from http://turizmgazetesi.com/news.aspx?id=5.

Evliyaoğlu, S. (1994). Türkiye turizm coğrafyası ve Türkiye coğrafyası'nın ana hatları. Gazi Üniversitesi.

EUROSTAT (2013). Average duration of inbound trips by residents from other EU-28(') countries - 2013, Retrieved October 15, 2015, from http://ec.europa.eu/eurostat/statisticsexplained/index.php/File:Average_duration_of_inbound_trips_by_residents_from_other_EU28(\%C2\%B9)_countries,_2013_(Nights)_updated.png

Fakeye, P. C.,\& Crompton, J. R. (1991). Image differences between prospective, first time, and repeat visitors to the lower Rio Grande valley. Journal of Travel Research, 30(2), 10-16.

Falk, E. B., Berkman, E. T., Mann, T., Harrison, B., \& Lieberman, M. D. (2010). Predicting persuasion-induced behavior change from the brain. The Journal of Neuroscience, 30(25), 8421-8424.

Fletcher, J. (1995). Economics and forecasting-economic impact. In S. F. Witt, \& L. Moutinho (Eds.), Tourism marketing and management handbook. Englewood Cliffs, NJ: Prentice-Hall.

Fuchs, G. (2013). Low Versus High Sensation-seeking Tourists: a Study of Backpackers' Experience Risk Perception. International Journal of Tourism Research, 151, 81-92.

Fuchs, G., \& Reichel, A. (2011). An exploratory inquiry into destination risk perceptions and risk reduction strategies of first time vs. repeat visitors to a highly volatile destination. Tourism Management, 32(2), 266-276.

Fyall, A., Garrod, B., \& Wang, Y. (2012). Destination collaboration: A critical review of theoretical approaches to a multidimensional phenomenon. Journal of Destination Marketing \& Management, 1(1), 10-26.

Gallarza, M. G., Gil, I., \& Caldero' n, H. (2002). Destination image: Towards a conceptual framework. Annals of Tourism Research, 29(1), 56-78.

GALLUP (2015). Positive Experience Index Survey. Retrieved September 15, 2015, from: ttp://www.gallup.com/poll/182009/mood-world-upbeat-international-happiness-day.aspx.

Gartner, W. C., (1989). Tourism image: Attribute measurement of state tourism products using multidimensional scaling techniques. Journal of Travel Research, 28(Fall), 16-20.

George, R. (2003). Tourists' perceptions of safety and security while visiting Cape Town. Tourism Management, 24, 575585.

George, R. (2010). Visitor perceptions of crime-safety and attitudes towards risk: The case of Table Mountain National Park, Cape Town. Tourism Management, 31(6), 806-815.

Gnoth, J. (2007). The structure of destination brands: Leveraging values. Tourism Analysis, 12, 345-358. 
Goffman, E., (1959), The Presentation of Self in Everyday Life, New York: Doubleday.

Goldberg, J. H., Probart, C. K., \& Zak, R. E. (1999). Visual search of food nutrition labels. Human Factors, 41, $425-437$.

Gordon, R., \& Ciorciari, J. (2017). Social marketing research and cognitive neuroscience. In Formative Research in Social Marketing (pp. 145-163). Springer Singapore.

Graham, D. J., \& Jeffery, R. W. (2012). Location, location, location: Eye-tracking evidence that consumers preferentially view prominently positioned nutrition information. Journal of American Dietetic Association, 111, 1704-1711.

Grönroos, C. (1990). Service management: A management focus for service competition. International Journal of Service Industry Management, 1(1), 6-14.

Grönroos, C. (2007). In Search of a New Logic for Marketing: Foundations of Contemporary Theory. Chichester: Wiley.

Hall, C. M. (1994). Tourism and politics: Policy, power and place. New York: Wiley.

Hall, C. M., \& O'Sullivan, V. (1996). Tourism, political stability and violence. In A. Pizam \& Y. Mansfeld (Eds.), Tourism, crime and international security issues (pp. 105-121). New York: Wiley.

Hall, C. M. (2002). Travel safety, terrorism and the media: The significance of the issue-attention cycle. Current Issues in Tourism, 5(5), 458-466.

Hall, C. M. (2010). Crisis events in tourism: Subjects of crisis in tourism. Current issues in Tourism, 13(5), $401-417$.

Hedgcock, W. M., Vohs, K. D., \& Rao, A. R. (2012).Reducing self-control depletion effects through enhanced sensitivity to implementation: Evidence from fMRI and behavioral studies. Journal of Consumer Psychology, 22(4), 486-495.

Henderson, P. W., Cote, J. A., Leong, S. M., \& Schmitt, B. (2003). Building strong brands in Asia: Selecting the visual components of image to maximize brand strength. International Journal of Research in Marketing, 20(4), 297313.

Hofstede, G., Hofstede, G. J., \& Minkov, M. (2015). Cultures and organizations: Pyramids, machines, markets, and families: Organizing across nations. In Jay Shafritz,J. \& Ott, Yong Jang (Eds). Classics of Organization Theory (pp. 314-335), United Kingdom: CENGAGE Learning.

Ho, S., \& Chua, H. F. (2013). Neurobiological bases of self-reference and deliberate processing in tailored health communication. In Social Neuroscience and Public Health (pp. 73-82). Springer New York.

Hunt, J. D. (1971). Image: A factor in tourism. Unpublished PhD dissertation thesis, Fort Collins, CO: Colorado State University.

Isaac, R. K., \& Çakmak, E. (2014). Understanding visitor's motivation at sites of death and disaster: the case of former transit camp Westerbork, the Netherlands. Current Issues in Tourism, 17(2), 164-179.

Jeuring, J. H. (article in press). Discursive contradictions in regional tourism marketing strategies: the case of Fryslân, The Netherlands. Journal of Destination Marketing \& Management.

Jing, N., \& Rong,L.( 2010). City marketing from the perspective of Shanghai WorldExpo. Orient Academic Forum (pp. 8698). Retrieved September 01, 2015, from seiofbluemountain.com/search/index.php?act=all\&name=pLUpRong $\rangle$.

de Jong-Meyer, R., \& Hubert, W., (1990). Psychophysiological response patterns to positive and negative film stimuli. Biological psychology, 31(1), 73-93.

de Jong-Meyer, R \&Hubert, W., (1991). Autonomic, neuroendocrine, and subjective responses to emotion-inducing film stimuli. International Journal of Psychophysiology, 11(2), 131-140.

Kavaratzis, M., \& Ashworth, G. (2007). Partners in coffeeshops, canals and commerce: Marketing the city of Amsterdam. Cities, 24(1), 16-25.

Keller, K. (1993). Conceptualizing, measuring, and managing customer-based brand equity. Journal of Marketing, 57(1), $1-22$.

Kim S.S., Chun H.J., \& Petrick J.F., (2005). Positioning analysis of overseas golf tour destinations by Korean golf tourists. Tourism Management, 26(6), 905-917.

Koc, E. (2000) The role and potential of marketing communications in the Turkish domestic tourism market (Unpublished doctoral thesis). Oxford Brookes University, Oxford.

Koc, E. (2002) The impact of gender in marketing communications: The role of cognitive and affective cues. Journal of Marketing Communications, 8 (4), 257-75

Koc, E., \& Altinay, G. (2007). An analysis of seasonality in monthly per person tourist spending in Turkish inbound tourism from a market segmentation perspective tourism management. Tourism Management, 28 (1), 227-237. 
Koc, E. (2009). A Review of country competitiveness, tourism industry performance and research performance relationships. Competitiveness Review, 19 (2), 119-133.

Koc, E., \& Boz, H. (2014a). Psychoneurobiochemistry of Tourism Marketing, Tourism Management, 44, 140-148

Koc, E., \& Boz, H. (2014b) Triangulation in tourism research: A bibliometric study of top three tourism journals. Tourism Management Perspectives, 12, 9-14.

Koc, E. (2015) Hizmet pazarlaması ve yönetimi. Seçkin Yayıncılık, Ankara.

Költringer, C., \& Dickinger, A. (2015). Analyzing destination branding and image from online sources: A web content mining approach. Journal of Business Research. 68(9), 1836-1843

Koc, E. (2015b). Handbook of scales in tourism and hospitality research. Tourism Management, (49), 43-44.

Kozak, N., \& Kozak, M. (2008). Information sources available to visitors: A segmentation analysis. Tourism Review, 63(4), 4-12.

Krippendorf, J. (1987a). The holiday makers: Understanding the impact of leisure and travel. Oxford: Heinemann Professional Publishing.

Krippendorf, J. (1987b). Tourism in Asia and the Pacific. Tourism Management, June: 137-139.

Lang, P. (1995). The emotion probe: Studies of motivation and attention. The American Psychologist, (50) 5,372-385.

Lang, A., Bolls, P., Potter, R. F., \& Kawahara, K. (1999). The effects of production pacing and arousing content on the information processing of television messages. Journal of Broadcasting and Electronic Media, 43, 451-475.

Lang, A., Zhou, S., Schwartz, N., Bolls, P. D., \& Potter, R. F. (2000). The effects of edits on arousal, attention, and memory for television messages: When an edit is an edit can an edit be too much? Journal of Broadcasting \& Electronic Media, 44, 94-109.

Laubrock, J., Engbert, R., Rolfs, M., \& Kliegl, R. (2007). Microsaccades are an index of covert attention: Commentary on Horowitz, Fine, Fencsik, Yurgenson, Wolfe. Psychological Science, 18, 364-366.

Lean, H. H., \& Smyth, R. (2009). Asian financial crisis, avian flu and terrorist threats: Are shocks to Malaysian tourist arrivals permanent or transitory? Asia Pacific Journal of Tourism Research, 14(3), 301-321.

Lepp, A., \& Gibson, H. (2003). Tourist roles, perceived risk and international tourism. Annals of Tourism Research, 30(3), 606-624.

Liu, Y., Sourina, O., \& Nguyen, M. K. (2010, October). Real-time EEG-based human emotion recognition and visualization. In Cyberworlds (CW), 2010 International Conference on (pp. 262-269). IEEE.

Lovelock, C., \& Wirtz, W. (2007). Services marketing: People, technology, strategy, 6th ed. Upper Saddle River, NJ: Prentice Hall.

Luck, S. J. (2014). An introduction to the event-related potential technique. MIT press.

Lykins, A. D., Meana, M., \& Kambe, G. (2006). Detection of differential viewing patterns to erotic and non-erotic stimuli using eye-tracking methodology. Archives of Sexual Behavior, 35, 569-575.

Mansfeld, Y. (2006). The role of security information in tourism crisis management: The missing link. In Y. Mansfeld, \& A. Pizam (Eds.), Tourism, security \& safety from theory to practice. Burlington, MA: Elsevier, ButterworthHeinemann.

Martin, M., \& Jones, G. V. (1999). Motor imagery theory of a contralateral handedness effect in recognition memory: Toward a chiral psychology of cognition. Journal of Experimental Psychology: General, 128(3), 265.

Martín, H. S., \& Rodríguez del Bosque, I. A. (2008). Exploring the cognitive-affective nature of destination image and the role of psychological factors in its formation. Tourism Management, 29(2), 263-277.

Mawby, R. I. (2000). Tourists' perceptions of security: The risk-fear paradox. Tourism Economics, 6(2), $109-121$.

Mayo, E. J. (1973). Regional images and regional travel behavior. Research for changing travel patterns: Interpretation and utilization. In Proceedings of Travel Research Association 4th Annual Conference (pp. 211-218). Sun Valley, Idaho.

Menéndez, J. (2015, October). Classification of Basic Human Emotions from Electroencephalography Data. In Progress in Pattern Recognition, Image Analysis, Computer Vision, and Applications: 20th Iberoamerican Congress, CIARP 2015, Montevideo, Uruguay, November 9-12, 2015, Proceedings (Vol. 9423, p. 108). Springer.

Morgan, N., \& Pritchard, A. (2002). Contextualizing destination branding. In N. Morgan, A. Pritchard, \& R. Pride (Eds.), Destination branding: Creating the unique destination proposition (pp. 11-41). Oxford: Butterworth-Heinemann. 
Noy, C., \& Kohn, A. (2010). Mediating touristic danger scapes: The semiotics of state travel warnings issued to Israeli tourists. Journal of Tourism and Cultural Change, 8(3), 206-222.

Ozcan, B., \& Erdogan, S. (2015). Are Turkey's tourism markets converging? Evidence from the two-step LM and threestep RALS-LM unit root tests.Current Issues in Tourism, 1-18.

Pearce, P. L. (1988). The Ulysses factor: Evaluating visitors in tourist settings. New York: Springer.

Phillips, B. (1985). Sociological research methods: An introduction. Homewood, Ill: Dorsey.

Piekarz, M., Jenkins, I., \& Mills, P. (2015). Risk and Safety Management in the Leisure, Events, Tourism and Sports Industries. Oxford: CABI.

Pike, S. (2002). Destination image analysis - A review of 142 papers from 1973 to 2000.Tourism Management, 23(5), 541-549.

Pike, S. (2005). Tourism destination branding complexity. Journal of Product \& Brand Management, 14(4), $258-259$.

Pike, S. (2009). Destination brand positions of a competitive set of near-home destinations. Tourism management, 30(6), 857-866.

Pike, S., \& Ryan, C. (2004). Destination positioning analysis through a comparison of cognitive, affective, and conative perceptions. Journal of travel research, 42(4), 333-342.

Pizam, A., Tarlow, P. E., \& Bloom, J. (1997). Making tourists feel safe: Whose responsibility is it? Journal of Travel Research, 36(1), 23-28.

Pizam, A., \& Mansfeld, Y. (1996). Tourism, crime and international security issues. NewYork: John Wiley \& Sons.

Prideaux, B., \& Master, H. (2001). Reducing risk factors for international visitors in destinations. Asia Pacific Journal of Tourism Research, 6(2), 24-32.

Qu, H., Kim, L. H., \& Im, H. H. (2011). A model of destination branding: Integrating the concepts of the branding and destination image. Tourism Management, 32(3), 465-476.

Rayner, K., Rotello, C. M., Stewart, A. J., Keir, J., \& Duffy, S. A. (2001). Integrating text and pictorial information: eye movements when looking at print advertisements. Journal of Experimental Psychology: Applied, 3, 219-226.

Rayner, K., Miller, B., \& Rotello, C. M. (2008). Eye movements when looking at printed advertisements: the goal of the viewer matters. Applied Cognitive Psychology, 22, 697-707.

Reeves, B., Lang, A., Kim, E. Y., \& Tatar, D. (1999). The effects of screen size and message content on attention and arousal. Media Psychology, 1(1), 49-67.

Reichel, A., Fuchs, G., \& Uriely, N. (2007). Perceived risk and the noninstitutionalized tourist role: The case of Israeli student ex-backpackers. Journal of Travel Research, 46(2), 217-226.

Reisinger, Y., \& Mavondo, F. (2005). Travel anxiety and intentions to travel internationally: Implications of travel risk perception. Journal of Travel Research, 43(3), 212-225.

Richter, L.L., \& Waugh, J.R. (1986).Terrorism and tourism as logical companions. Tourism Management, 7(4), $230-238$.

Roe, J. J., Aspinall, P. A., Mavros, P., \& Coyne, R. (2013). Engaging the brain: The impact of natural versus urban scenes using novel EEG methods in an experimental setting. Journal of Environmental. Science, 1(2), 93-104.

Roehl, W.S. (1995). The June4, 1989, Tiananmen Square incident and Chinese tourism. In: A. A. Lew ,\& L. Yu (Eds.), Tourism in China: Geographic, political and economic perspectives. Boulder,CO: West View Press.

Samant, S. S., \& Seo, H. S. (2016). Effects of label understanding level on consumers' visual attention toward sustainability and process-related label claims found on chicken meat products. Food Quality and Preference, 50 (2016) 48-56.

Sayarı, S. (2016). Back to a predominant party system: The November 2015 snap election in Turkey. South European Society and Politics, 21(2), 263-280.

Seabra, C., Dolnicar, S., Abrantes, J. L., \& Kastenholz, E. (2013).Heterogeneity in risk and safety perceptions of international tourists. Tourism Management, 36, 502-510.

Seo, H. S., Roidl, E., Müller, F., \& Negoias, S. (2010). Odors enhance visual attention to congruent objects. Appetite, 54(3), 544-549.

Sheng, H., \& Joginapelly, T. (2012). Effects of web atmospheric cues on users' emotional responses in e-commerce. AIS Transactions on Human-Computer Interaction, 4(1), 1-24.

Shin, Y. S. (2005). Safety, security and peace tourism: The case of the DMZ area. Asia Pacific Journal of Tourism Research, 10(4), 411-426. 
Simone-Charteris, M. T., \& Boyd, S. W. (2010). Northern Ireland re-emerges from the ashes: The contribution of political tourism towards a more visited and peaceful environment. In O. Moufakkir \& I. Kelly (Eds.), Tourism, progress and peace (pp. 179-198). UK: CABI.

Simons, R.F., Detenber, B.H., Roedema, T.M., \& Reiss, J.E., (1999). Emotion processing in three systems: The medium and the message. Psychophysiology, 36, 619-627.

Simpson, P. M., \& Siguaw, J. A. (2008). Perceived travel risks: The traveller perspective and manageability. International Journal of Tourism Research,10(4), 315-327.

Sirakaya, E., \& Woodside, A. (2005).Building and testing theories of decision making by travellers. Tourism Management, 26, 815-832.

SKIFT (2015).Six Charts Showing Which Countries Have Strongest Tourism Brands Retrieved December 1, 2015, from http://skift.com/2015/11/24/6-charts-showing-which-countries-have-strongest-tourism-brands/

Smith, H. W. (1975). Strategies of social research: The methodological imagination. Englewood Cliffs, NJ: Prentice-Hall.

Sonmez, S. F. (1998). Tourism, terrorism and political instability. Annals of Tourism Research, 25(2), 416-456.

Sönmez, S. F., \& Graefe, A. (1998a). Influence of terrorism risk on foreign tourism decisions. Annals of Tourism Research, 25(1), 112-144.

Sönmez, S. F., \& Graefe, A. R. (1998b). Determining future travel behavior from past travel experience and perceptions of risk and safety. Journal of Travel Research, 37(2), 171-177.

Sonmez, S.F. (1998c). Tourism, terrorism and political instability. Annals of Tourism Research, 25(2), 416-456.

Stanley, J., \& Stanley, L. (2014). Food Tourism: A Practical Marketing Guide. Oxfordshre: CABI.

Stepchenkova, S., \& Li, X. R. (2014). Destination image: Do top-of-mind associations say it all?. Annals of Tourism Research, 45, 46-62.

Stepchenkova, S., \& Mills, J. E. (2010). Destination image: A meta-analysis of 2000-2007 research. Journal of Hospitality Marketing \& Management, 19(6), 575-609.

Tasci, A. D., \& Kozak, M. (2006). Destination brands vs. destination images: Do we know what we mean? Journal of Vacation Marketing, 12(4), 299-317.

Taşkın, C., \& Karadamar, A. A. (2016a). Destinasyon marka bağıı̆ı̆ı: Yabancı turistler üzerine Diyarbakır kentinde bir araştirma. Journal of Administrative Sciences/Yönetim Bilimleri Dergisi, 14(28).

Taşkın, Ç., \& Karadamar, A. A. (2016b). Destinasyon marka bağııı̆ı̆ı etkileyen öncüller üzerine Diyarbakır kentinde bir araştirma. Paradoks Ekonomi, Sosyoloji ve Politika Dergisi, 12(2).

Tillyer, R., Engel, R. S., \& Cherkauskas, J. C. (2010) Best practices in vehicle stop data collection and analysis. Policing: An International Journal of Police Strategies \& Management, 33(1), 69-92.

Turkish State Institute of Statistics (2015). Tourism Statistics, Retrieved October 15, 2015, fromhttp://www.tuik.gov.tr/PreTablo.do?alt_id=1072

Turok, I. (2009). The distinctive city: Pitfalls in the pursuit of differential advantage. Environment and Planning, A, 41(1), 13-30.

Tversky, A., \& Kahneman, D. (1992). Advances in prospect theory: Cumulative representation of uncertainty. Journal of Risk and uncertainty, 5(4), 297-323.

Uysal M, Chen JS, Williams DR. 2000.Increasing state market share through a regional positioning. Tourism Management, 21(1): 89-96.

Valenzi, S., Islam, T., Jurica, P., \& Cichocki, A. (2014). Individual Classification of Emotions Using EEG. Journal of Biomedical Science and Engineering, 7(8), 604-621.

Verhage, B. J., Yava, U., \& Green, R. T. (1990). Perceived risk: a cross-cultural phenomenon? International Journal of Research in Marketing, 7(4), 297-304.

Witt, F. S. T., \& Moutinho, L. (1995). Tourism Marketing and Management Handbook, Hertfordshire: Prentice Hall.

Wong, P. P., \& Teoh, K. (2015). The influence of destination competitiveness on customer-based brand equity. Journal of Destination Marketing \& Management, 4, 206-212.

Woosnam, K. M., Shafer, C. S., Scott, D., \& Timothy, D. J. (2015). Tourists' perceived safety through emotional solidarity with residents in two Mexico-United States border regions. Tourism Management, 46, 263-273.

World Economic Forum (WEF) (2015). The Travel \& Tourism Competitiveness Report 2015 
$\begin{array}{llll}\text { Retrieved November } & 15, & 2015, & \text { from }\end{array}$ http://www3.weforum.org/docs/TT15/WEF_Global_Travel\&Tourism_Report_2015.pdf

World Tourism Organization (WTO) (2009) UNWTO World Tourism Barometer. Retrieved October 15, 2015, from United Nations World Tourism Organization: www.unwto.org/facts/eng/barometer.htm

World Tourism Organization (WTO) (2014), Tourism Highlights 2014, Retrieved October 20, 2015 from http://dtxtq4w60xqpw.cloudfront.net/sites/all/files/pdf/unwto_highlights14_en_hr_0.pdf.

Van Loo, E. J., Caputo, V., Nayga, R. M., Jr., Seo, H. S., Zhang, B., \& Verbeke, W. (2015). Sustainability labels of coffee: Consumer preference, willingness-to-pay and visual attention to attributes. Ecological Economics, 118, $215-225$.

Vecchiato, G., Jelic, A., Tieri, G., Maglione, A. G., De Matteis, F., \& Babiloni, F. (2015). Neurophysiological correlates of embodiment and motivational factors during the perception of virtual architectural environments. Cognitive Processing, 16(1), 425-429.

Zauhar, J. (1994). Loisirs et Tourisme-convergence or divergence. Ottawa: Balfour Institute.

Zeithaml, V. A., Bitner, M. J. \& Gremler, D. D. (2006). Services marketing: Integrating customer focus across the firm. 4th ed. United Kingdom: McGraw-Hill Irwin.

Zenker, S., \& Beckmann, S. C., (2013). My place is not your place - Different place brand knowledge by different target groups. Journal of Place Management and Development, 6(1), 6-17.

Zhu, Z., \& Brilakis, I. (2009) Comparison of optical sensor-based spatial data collection techniques for civil infrastructure modeling. Journal of Computing in Civil Engineering, 23(3), 170-177. 
This Page Intentionally Left Blank 